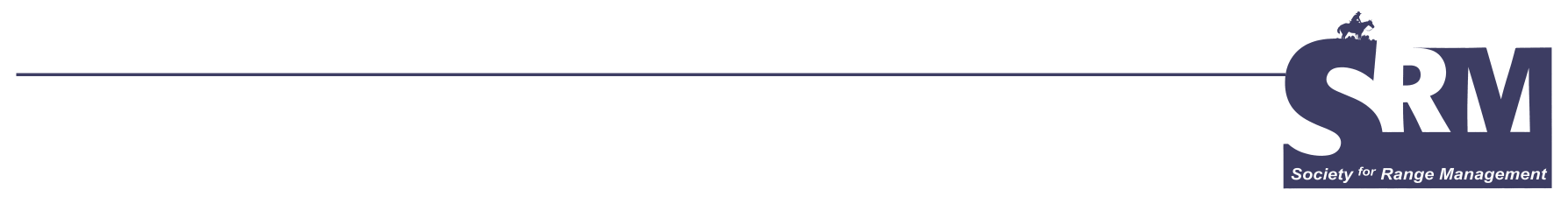

\title{
Our Youth-The Real Future of Range Management
}

\section{It is never too early to start learning about range management.}

\section{By Niels LeRoy Martin}

There is an old country ${ }^{0}$ western song lamenting the passing of singing western movie stars such as Roy Rogers and Gene Autry saying: "Who Are to Take Their Place?" It might also be said: "Who are to take the place of those who have long been dedicated to the proper management of our rangelands but who are now retired or retiring?"

here is a continuing dialogue going on in our society and among range professionals as a whole concerning what the future of range management will be. Discussions range from a proper name for the society and the Journal of Range Management (now Rangeland Ecology \& Management - that is one that the advocates of change have won) to how the public perceives us and what different roles our profession will adopt. We have seen a lot of technological changes with the advent of satellite imagery, handheld computers, and other digital gadgets. Just a little over 20 years ago, I was mapping vegetation manually on Mylar using LandSat imagery as a base, but cutting and pasting cross-hatching and symbols and making 3 separations for a color printing process. Now it is all computers, GIS, and digital imaging. What has not changed is the need for new range men and women to take the place of us old-timers who are now leaving active employment in the profession. Some of us like to think that we are irreplaceable and that no one can do it as well as we did, but the fact is that there are many highly talented young people waiting in the wings. What we have to do is enlight- en them about the importance of range management and about the opportunities that are waiting for them.

I refer to myself as an "accidental" high-school science teacher. After a career in range management that took me to about 25 countries on 4 continents, my wife and I settled on the plains east of Denver, Colorado, to be near most of our grown children. She began teaching at a small rural school in the tiny community of Agate. When the school was in need of a science teacher, she told the administration about me and I began teaching high school. That was almost 4 years ago. This experience has brought me into a world of youth that I believe provides me with a view that is unusual, if not unique, among those of our profession.

The youth of today face many challenges that we did not face when I was young, but they also have many opportunities for learning and growth that we did not have. The culture of drugs seems to have permeated our society to such an extent that even the students in our small schools are not immune to their reach. Television has brought into the homes of our youth social situations, language, and behavior that would have been abhorrent when I was young. On the other hand, the young people of today have such a wealth of knowledge at their fingertips that I cannot even imagine having that in my youth. They have computers, the internet, cell phones, pocket personal computers, digital cameras, satellite communications, and digital imagery to only mention a few on a long list of innovations that have such great potential in our profession. 


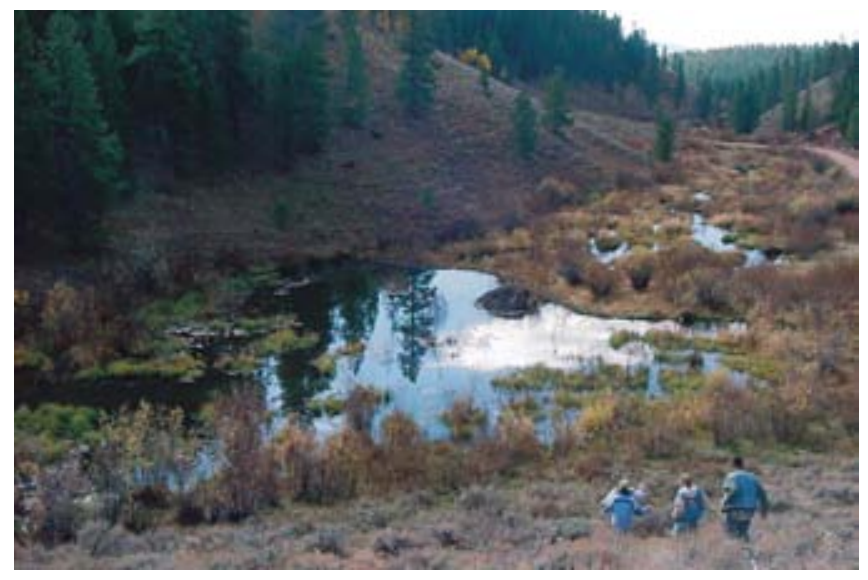

Students going to a beaver pond during a mountain-ecology field trip.

When I teach science at the high-school level, I marvel at all of the discoveries of the past 50 years. As I began to teach chemistry, I found out that the atom is not even constructed the same way that it was when I was young. Biology has expanded in so many ways. High-school students are learning things about plant physiology that were not taught to me until I was in my junior and senior years at college. They learn typing in elementary school or middle school and practice it every day as they chat on-line to their friends. They can communicate almost instantly with cell-phone text messaging (have any of you who are more than 40 years of age figured out how to quickly use those little keys to type in messages?).

At the trade-fair booths at Fort Worth, we saw a number of high-tech systems to collect resource data. There are new technologies becoming available every day that can be applied to range management and range science. Our youth have the background and the abilities to apply these technologies to the art and science of range management.

As a high-school science teacher with a background in range management, I approached the school administration about teaching some range-related courses using college texts and they eagerly agreed. We now have a program set up with one of the junior colleges so the students can get college credit for the courses concurrently with earning high-school science credits. I have taught introductory range management, animal science, and plant identification. This provides an opportunity for the students to have an exposure to the field of range management before they leave high school.

Many students are capable of reaching far beyond the skills and knowledge base we normally expect from teenagers. By providing high-school students with challenges outside of normal expectations, they are able (and usually willing) to learn as well as students in our colleges and universities. I have students who have learned genus, species, and common names for most of the plants used in the plant-identification contest at our national meetings. They also collect rangeland plants and press and mount them and add them to a growing collection for our highschool herbarium. I have a few exceptional high-school sophomores who are able to put together research papers that would be completely acceptable in a college science course because it is required of them and because they rise to the challenge.

Since my health is poor and I lack the stamina necessary to keep up with 14- to 18-year-old youth on a daily basis, I find it necessary to leave high-school teaching. The program that I initiated in Agate High School will not, however, retire with me. We are now starting an Agricultural Education/Future Farmers of America (FFA) program at the school and the administration is adamant about keeping the rangemanagement curriculum that we have been teaching. The agriculture teacher will teach the college-level courses as part of the advanced level of the agriculture curriculum, and students will continue to be challenged and will be encouraged to reach beyond their normal high-school comfort zone.

Agate High School is not unique in that there are numerous rural (and even urban) high schools where rangemanagement programs may be introduced. Agricultural Education/FFA programs throughout the West and Southeast and anywhere grazing land is important in the local agricultural economy could benefit from the introduction of college-level or advanced-placement range-management curricula. Many (at least in Colorado) already have an introduction to range management at a basic level and they participate in range judging as a part of the FFA program, just as FFA members everywhere judge livestock. It is not a huge step to go on to the next level of actually developing a curriculum with a few college-level courses that will allow some of the students to specialize.

How do we as members of SRM help to make this happen? Get involved in high-school education at a local level. I am not advocating that large numbers of us become highschool teachers. My situation was unique, but I believe that many of the lessons I learned can be applied to a very high percentage of our high schools. Following are some of my thoughts on how this may be done:

1. Offer your talents in range management to your local school district. If there is an Agricultural Education

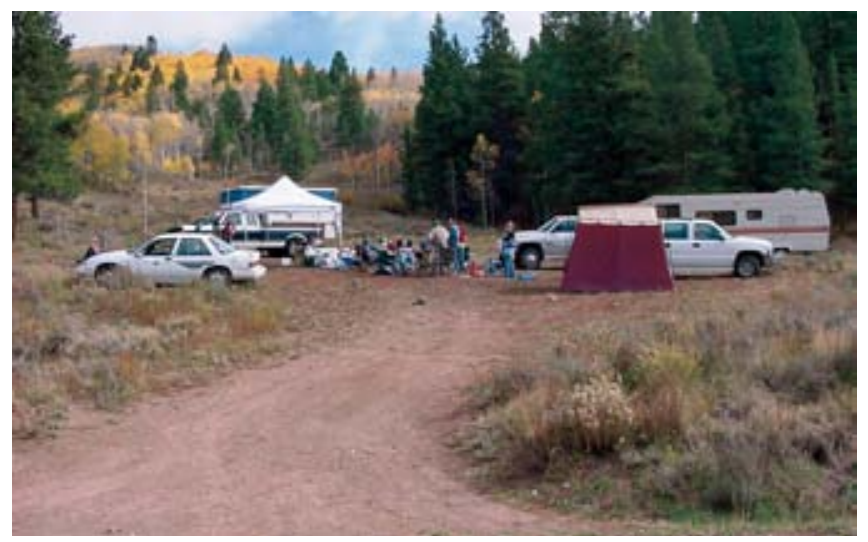

Camp along Blacktail Creek in Routt National Forest, Colorado. 
department, visit with the teacher and volunteer to assist by speaking to the students about rangelands and range management. If the teacher is so inclined, offer to help organize a range-management course or even a full curriculum that he/she could teach with your help.

2. Assist your section youth committee and find out what you can do to help promote the High School Youth Forum at the annual meeting.

3. If your section has a youth range camp or range-judging contest, volunteer to help with it. Help find candidates from among local high-school youth for these activities. If there are no such programs in your section, work with range extension specialists and your section to get them established. It was the Oregon range-management camp that introduced me to range management. I was in FFA and was selected to participate in a camp in eastern Oregon when Barry Freeman was the range extension specialist there. I had an interest in botany and loved to work on the western Oregon ranches near my home but had not even heard of range management until that time. It was a perfect fit for me and I have been very happy that I went to that camp and learned of our profession.

4. Become involved with local school politics and let your school board know that range management is important and that students should have the opportunity to learn about rangelands. Better yet, run for the school board and be in a prime position to have a positive impact upon the youth of your area.

5. For those who are retired, find out what the requirements are to become a substitute teacher. Depending on the requirements of your state and local school district, you may already have the qualifications and, with just a little paperwork, could be substituting occasionally for the science or agricultural teacher. That would be a perfect way to get involved with the school and perhaps have some influence on having some range management taught in your local area. Even substituting for the elementary and middle school may allow for teaching about rangelands on a very basic level.
I recognize that we may not find many students in any one place that will become range managers and members of the Society. We will, however, have a very positive impact upon the way the general public views rangelands. We will develop doctors, lawyers, teachers, firemen, soldiers, scientists, engineers, and people in all the professions that will have an appreciation for range management. And, yes, there will be a few who will be touched like I was, with the desire to become involved in the profession of range management.

I don't know how many, if any, of my students and former students may end up in a range-related career. I do know that some will be ranchers. These future ranchers will have a better understanding of, and be better stewards for, the rangelands on which their cattle will graze. I have already witnessed some of this. Some of their parents have commented that their sons and daughters have been pointing out plants that they know and have made comments about potential for water developments and about better grazing-management ideas. One of my former students went on to college and began majoring in agriculture. She then changed to nursing. She won't be in a field directly related to range management, but she will be a nurse that understands rangelands and range-related issues.

The rangelands of the world are critical producers of food, fiber, water, energy, and wildlife. They provide recreational opportunities and aesthetic values. The future of these lands lies in the hands of our youth. We as a society can work together to educate our young people so that their minds will be enlightened and their hands skilled in providing a bright future for the lands we have worked so hard to conserve. Their education will ensure that these rangelands will be available for the use and pleasure of innumerable future generations.

The author has been teaching at a rural country school in Eastern Colorado. 